\title{
Conversion of Carboxylic Acids to Aldehydes with Cyclic Dialkyldiaminoaluminum Hydrides ${ }^{\dagger}$
}

\author{
Jin Soon Cha* and Suk Joung Moon \\ Department of Chemistry, Institute of Vatural Sciences and Institute of vew Haterial Chemistrv, \\ leangham Lniversin; Grongsan 712-719. Lorea \\ Recened Harch 19, 2002
}

Key Words : Reduction Carboxylic acids. Aldehydes synthesis. Cỵclic dialkỵldianuinoaluminum hydrides

A series of bis(dialkylamino)aluminum hy dride reagents. which possesses various dialkylamines of different steric environments, has been reported as good reducing agents for the direct conversion of free carboxylic acids to the corresponding aldehy des. ${ }^{1-3}$ In continuation of our eflorts to explore new reducing agents for such transformation. we prepared cyclic dialky ldiaminoaluminum hydrides (1 and 2) and cxamined their gencral reducing action toward various organic functional groups. In the course of a systcmatic study. we found that these cyclic diaminoaluminum hydrides appear to be the reagents of choice for converting aromatic carboxy lic acids to the corresponding aldchydes. Hercin. we report such a transformation using newly-devised reducing agents.<smiles>[CH]N1CCN(C)[AlH]1</smiles><smiles>CCN1CCN(CC)[AlH]1</smiles>

Results and Discussion

The reagents 1 and 2 are readily prepared by a simple reaction of aluminum hydride $\left(\mathrm{AlH}_{3}\right)$ with $N, N^{\prime}$-dialkylelly lenediamine $(1 . R=M c: 2 . R=E l)$ in $T H F(E q . ~ l)$. A solution of aluminum hydride in THF reacts with diamines readily to crolve 2 cquiv of hỵdrogen.

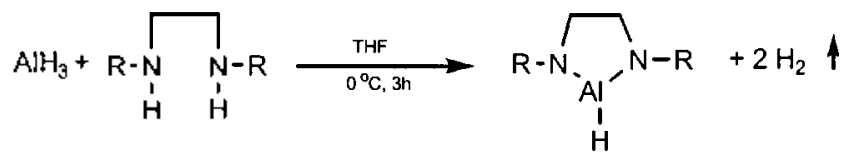

$$
\begin{aligned}
& (\mathrm{R}=\mathrm{Me}, \mathrm{Et}) \\
& \text { 1 2 }
\end{aligned}
$$

${ }^{27} \mathrm{Al}$ NMR showed a doublel $\left(J_{\mathrm{Nl}-\mathrm{H}}=265 \mathrm{H} \%\right.$ for 1 and 360$)$ $\mathrm{H} \%$ for 2 ) centered at $\delta 108$ for 1 and $\delta 106$ for 2 relative to $\left[\mathrm{Al}\left(\mathrm{H}_{2} \mathrm{O}\right)_{6}\right]^{3 \cdot}$ as a reference. A solution of the cyclic dianinoaluminum hydride in THF displayed typical absorption in the IR: a strong absorption around $1820 \mathrm{~cm}^{-1}$. attributed to the Al-H stretching vibration. The reagents

†This paper is dedicated to Prolicssor Sang Chul Shim for his distinguished achicvements in ehemistry. were stable for at least a month when the THF solution of reagents was maintained under a positive pressure of nitrogen at $0{ }^{\circ} \mathrm{C}$.

The general reducing power of these reagents toward organic functionalitics appeared to be much weaker than that of parent aluminum hydride ${ }^{4}$ : an cxtended period of reaction lime at room temperature was necded to reduce even aldehydes and ketones. Howerer. rather surprisingly. the reduclion of aromatic carboxylic acids procecded relatively laster after the crolution of I equiv hydrogen and stopped at the aldehyde stage. This phenomenon indicates that the acy loxyalane intermediate 3 is favorable to the reduction by the reagent but the resultant aldehyde intermediate $f$ is relatively stable toward the further reduction (Eq. 2). Howcrer. the reaction of aliphatic carboxylic acids provided unsatisfactory results : over reduction to the alcohol stage is layorable under these reaction conditions.

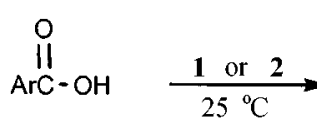

3

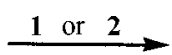<smiles>[R]N1CCN([R])[Al]1O[Ge]</smiles>

3<smiles></smiles>

4
We perfomed all the reductions under the standardised reaction conditions at $25^{\circ} \mathrm{C}$ : we have not tried to get a maximum yicld in cach reaction of carboxylic acids. The general trend of aldehyde synthesis from carboxylic acids with these reagents has been examined and the results are summarized in Table 1.

Both the reagents reduce aromatic carboxylic acids to 
Table 1. Ruaction of Carbonylic Acids uith Cuclic Dialkyldianninoulumunum Ilydrides at $25^{\circ} \mathrm{C}$ in 'letrahn drolinan"

\begin{tabular}{|c|c|c|c|}
\hline \multirow{2}{*}{ Carboxylic acids } & \multirow{2}{*}{ linne $(1)$} & \multicolumn{2}{|c|}{ Yield of aldehyde $(\%)^{b}$} \\
\hline & & Keragent l & Rẹgent 2 \\
\hline bentuoic & 72 & 85 & 84 \\
\hline$\alpha$-ntaphthoic & 72 & 87 & 85 \\
\hline$o$-toluic & 72 & 68 & 64 \\
\hline m-loluic & 72 & 75 & 76 \\
\hline$p$-loluic & 72 & 70 & 60 \\
\hline$\theta$-anisic & 48 & 78 & 72 \\
\hline$p$-anisic & 24 & 79 & 75 \\
\hline o-chlorobenzoic & 24 & 63 & 61 \\
\hline$p$-chlorobenzoic & 72 & 88 & 75 \\
\hline terephthalic ${ }^{2}$ & 72 & 75 & 71 \\
\hline cimmanic & 24 & 78 & 70 \\
\hline hexamoic & 72 & $\$ 1$ & 32 \\
\hline trimethỵlacetic & 72 & 30 & 27 \\
\hline cyclohexanectarboxylic & 72 & 42 & 54 \\
\hline isobultric & 72 & 52 & 46 \\
\hline crotonic & 24 & 52 & 44 \\
\hline
\end{tabular}

"Ratio of reagent to compound is 2.1:1. " Analyzed by GC using a suitable intemal standard. The product other than aldeho is alcohol along with unreacled starting carboxylic acid. "Reagent to compound is $4.2: 1$

aldehydes in 2-3 davs at room temperature in yiclds of 70 $90 \%$. showing no significant bias in yiclds in the substitutents on the benzene ring. Dicarboxylic acid. such as terephthalic acid. provides the corresponding dialdchyde in viclds of $70-75 \%$. $\alpha . \beta$-Unsalurated carboxylic acid. such as cinnamic acid. works equally well. Howercr. the viclds from aliphatic carboxylic acids with both the reagents are not satisfactory under the reaction conditions. The yiclds are only in the range of $30-50 \%$. along with the reduction products of the corresponding alcohols.

Gencrally. in aspect of the efliciency for aldehydes synthesis from carboxylic acids. the reagent 1 is better than 2: the reagent 1 favors in a yield of aldelyyde and cost. The yields of aldelydes obtained by these reagents and dialkylaminoalumimum lydrides 1-3 are guite similar. However. the reductions by the former proceed under the much milder reaction conditions than the reductions by the latter: the latter reagents require drastic reaction conditions of a refluxing-THF temperature and a large excess amount of reagent up to four equivalents to get satisfactory results.

There have appeared various useful methods for transformation of carboxylic acids to aldelydes. ${ }^{1-3,5}$ Among them. thexy/haloboranes, ${ }^{56}$ the 9-BBN system with metal lydrides ${ }^{7}$ and the reduction-oxidation procedure ${ }^{\circledR}$ seem to afford the most satisfactory results. However. every reducing system possesses its own limitation in use. For examples, the vields of aromatic aldehydes by thexy/haloboranes ${ }^{5.6}$ are relatively low and variable upon the substituents on benzene ring: the 9-BBN system with metal hydrides ${ }^{7}$ and the reductionoxidation procedure can not be compatible with readily reducible functions other than carboxylic acid group. Therefore. chemists should find which procedure is suitable for their compounds to be transformed. Consequently: this method should provide another procedure of choice to effect such conversion.

\section{Experimental Section}

All glassware utilized in this experiment was dricd in oven. asscmbled hot. and cooled with a stream of dry nitrogen. All reactions were carricd out under a static pressure of nitrogen atmospherc. Experimental techniques used in handling air- and moisture-sensitive materials are described elscwhere. THF was dricd over a 4 A molecular sieve and distilled from sodium benzophenone ketyl just prior to use. Lithium aluminum hydride (LAH) was obtained from the Aldrich Chemical $\mathrm{Co}$. and used directly without further purilication. $N, N$-dialkylethylenediamine from the Aldrich Chemical $\mathrm{Co}$. was purilied by distillation after drying over $\mathrm{KOH},{ }^{27} \mathrm{Al}$ NMR spectra were recorded on a Bruker AMX 300 spectrometer and all chemical shifts were reportcd in $\delta(\mathrm{ppm})$ relative to $\left.\mid \mathrm{Al}\left(\mathrm{H}_{2} \mathrm{O}\right)_{6}\right]^{3 .}$. IR spectra werc recorded on a Perkin-Elmer 1330 spectrometer. GC analy ses were performed with a Varian 3300 chromatograph using a 30-m DB-WAX capillary column.

Preparation of Aluminum Hydride Solution in THF. By means of a double-cnded necdle. $250 \mathrm{~mL}$ of $1.2 \mathrm{M}$ lithium aluminum hydride solution in THF $(300 \mathrm{mmol})$ was introduced into a 500 - $\mathrm{mL}$ flask. Fitted with an inlet port. rubber syringe cap. and a magnetic stirring bar and connected to a mercury bubbler via a reflux condenser. The flask was cooled to $0^{\circ} \mathrm{C}$ and maintaince at the temperature using a relrigcrating bath circulator. To this solution $29.5 \mathrm{~g}$ of methancsulfonic acid ( $308 \mathrm{mmol} .2 .5 \%$ cxcess) was added slowly by means of a hy podermic sy ringe. while stirring the solution vigorously. After the complete addition. the solution was permitted to stir for $\mathrm{I} h$. and then allowed to stand to permit the lithium sulfonate precipitate to settle. The clear. supernatent solution was analyzed for hydride by hydroly\%ing an aliquol with $2 \mathrm{~N} \mathrm{H}_{2} \mathrm{SO}_{4}-\mathrm{THF}(\mathrm{l}: 1)$ solution to indicate a concentration of $1.10 \mathrm{M}\left({ }^{27} \mathrm{Al}\right.$ NMR: $\left.\delta 127\right)$.

Preparation of Cyclic Dialkyldiaminoaluminum Hydride $(1,2)$ Solution in THF. The preparation of reagent $1\left(N, N^{\prime}-\right.$ dimethy lethylenedianninoaluminum hydride) is illustrative. In a $100-\mathrm{mL}$. round-bottomed flask was placed $30 \mathrm{mLL}$ of a $1.10 \mathrm{M}$ solution of $\mathrm{AlH}_{3}$ in THF (40 munol) and the solution was kept at 0 " $\mathrm{C}$ by using a refrigerating bath circulator. To this solution was added $3.92 \mathrm{~g}$ of $N, N$-dimethylethlenediamine ( $44 \mathrm{mmol})$ dropwise with vigorous stirring. After the complete addition, the solution was stirred for $3 \mathrm{~h}$. The concentration of the solution was estinated gasometrically to indicate $0.92 \mathrm{M}$. ${ }^{27} \mathrm{Al}$ NMR spectrum of the solution showed a doublet $\left(J_{\mathrm{A} \cdot \mathrm{II}}=265 \mathrm{~Hz}\right)$ at $\delta 106 \mathrm{ppnl}$. IR spectrum of the solution displayed a strong absorption at $1821 \mathrm{~cm}^{-1}$. attributed to the $\mathrm{Al}-\mathrm{H}$ stretching vibration.

General Procedure Used for Reductions. The following procedure was used for quantitative studies. The reduction of benzoic acid is described as an example of the experimental procedure. To a 50 -mL flask fitted with a rubber syringe cap on an inlet port. a magnetic stirring bar, and a bent adapter 
connected to a mercury bubbler wia a reflux condenser 8.7 $\mathrm{mL}$ of a solution of $0.92 \mathrm{M}$ reagent $1(8 \mathrm{mmol})$ was placed and the solution was maintained at $25^{\circ} \mathrm{C}$. To this solution 0.49) $\mathrm{g}$ of ben/oic acid $(4.0 \mathrm{mmol})$ in $4 \mathrm{~mL}$ of THF was injected slowly. One equiy of hydrogen was evolved immediatcly. After the complete evolution of hydrogen. a measured quantity of tridecane (ca. $2 \mathrm{mmol}$ ) as an internal standard was added. After $72 \mathrm{~h}$ a small portion of the reaction mixture was withdrawn and then quenched with $2 \mathrm{~N}$ $\mathrm{HCl}$. The aqueous layer was saturated with $\mathrm{MgSO}_{4}$, and the organic layer was washed with saturated $\mathrm{NaCl}$ solution. The organic layer dricd oy cr anhydrous $\mathrm{K}_{2} \mathrm{CO}_{3}$ was subjected to GC analysis to indicate the presence of benzaldehyde in a yicld of $85 \%$ along with $5 \%$ of benzyl alcohol and some unreacted starting benzoic acid.

Acknowledgment. The authors wish to acknowledge the financial support of the Korea Rescarch Foundation Grant (KRF-99-005-DO0054). The ${ }^{27} \mathrm{Al}$ NMR spectra were recorded on a Bruker AMX 300 spectrometer at the Yeungnam University lnstrumental Analysis Center.

\section{References}

1. Muraki. M: Mukayama. T. Chenishy Letl. 1974. 1447: 1975. 215.875
2. Hubert. T. D.: Eymat1. D. P.: Wiemer. D. F. f. Org. (Them 1984. 19. $227 \%$

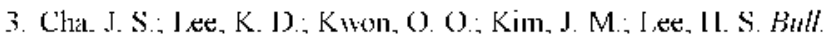
Son'm (hen. Soc. 1995. 16. 561.

4. (a) Brown. H. C.: Yoont. N. M. J. An Chem. Sox. 1966. 88. 1464. (b) Cha. J. S.: Brown. H. C.J. Ohg. Chkm 1993.58.3974.

5. (a) Brown. H. C.: Cha. T. S.: Nazer. B.: Yoon. N. M. J. im Chem. Soc. 1984, 106. 8(N)1. (b) Broun. H. C.. Che, I. S.; Yoon, N. M: Nazer 13.J. Org. (heth. 1987. 52. 5400.

6. (a) Cha J. S. Kim. J. Ii.. Oh. S. Y. I ee J. C. I ee. K. W. Tetrdhe(from Lett. 1987. 28. 2389. (b) Cha. T. S.: Kim. T. E.: Le. K. W. J. Org. (htm. 1987.52.5030.

7. (a) Cha. J. S.: Kim. T. E.: Oh. S. Y.: Kim. T. D. Tetrohedron Itett. 1987. 28. 4574. (b) Cha. J. S.: Kim. J. I.: Yoon, M. S.: Kim, Y. S

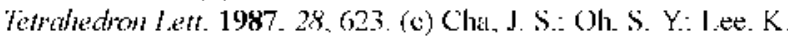

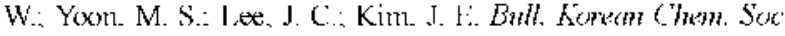
1988. 9. 48. (d) Cha. J. S.: Oh. S. Y.: Lee. K. W.: Yoon. M. S.: Lee. J. C.: Kim. J. E. Iteterocytes 1988. 27. 1595 , (c) Cha. I. S.: Lee. K. W: Yoon. M. S.: Lee. J. C. Bult Aorean (7hem. Soc. 1988. 9. 384. (I) Cha I. S. I ee I. C.: Yoon. M. S: Seo, J. B.: Kim, I. M. fbid. 1990, H. 76. (g) Cha. I. S. fbid 1992, 13,670.

8. (a) Cha. I. S.: Kim. J. M.: Churn. I. II: Kwon. O. O: I ee, J. C. Bull. Rorean (hem. Soc. 1998. 19. 730. (b) Cha. J. S.: Kim. I. M.: Chun. J. H.: Kwon. O. O.: Kwon. S. Y.: Han. S. W. Ibid. 1999. 20. 400. (c) Cha. T. S.: Lee. D. Y.: Kim. I. M. Org Prep. Proced /m. 1999. 31, 694. (d) Cha, J. S.: Patk. I. II. I .ee I). Y. Bull. Kontom Chem Soc. 2001. 22 325. (e) Cha. J. S.: Park. I. II.: Moon. S. I. Ibid. 2001, 22. I089)

9. Brown. H. C.: Kramer. G. W.: Lev. A. B.: Midland. M. M. Organic Symhesis via Bormes: Wiley-Interseience: Now York. 1975. 